\title{
РЕЦЕНЗІЇ. ХРОНІКА
}

\section{MICHAŁ DZIK. PRZEMIANY ZWYCZAJÓW POGRZEBOWYCH W MIĘDZYRZECZU BUGU I GÓRNEJ NARWI (XI-XV W.). - Tom I, II. - Rzeszów, 2015. - 321 s. / 255 s.}

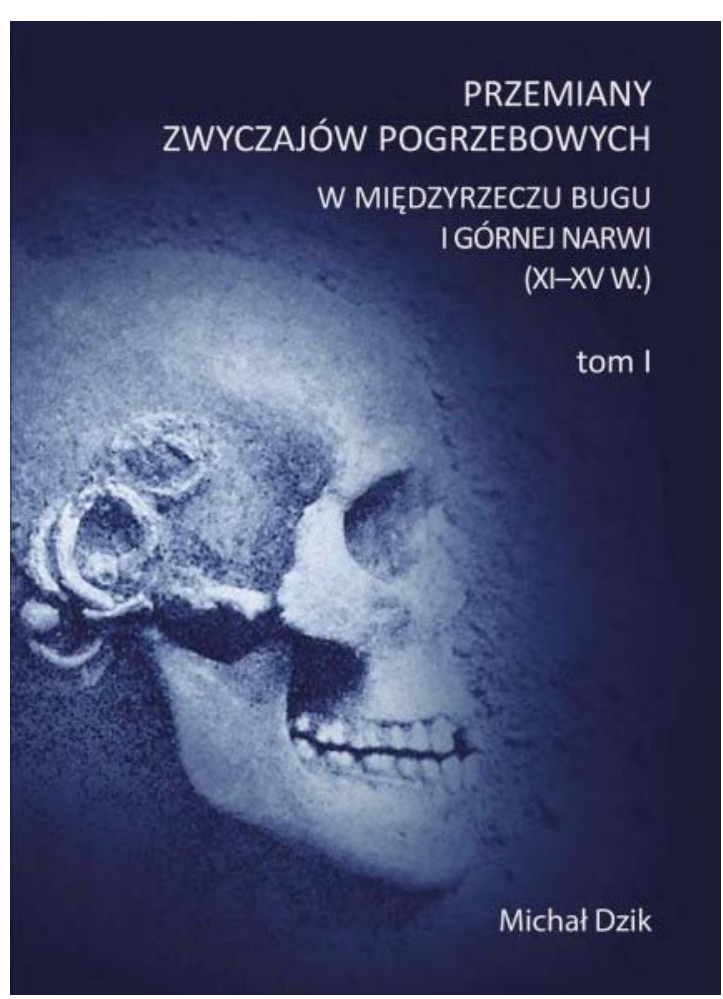

Духовну культуру давніх етносів, складова якої - звичаї, норми, цінності, знання, релігійні вірування тощо, неможливо відтворити лише на основі писемних, зображувальних чи усних джерел, а коли йдеться про дописемний період чи не єдині джерела інформації - археологічні дані. Важливий вияв духовної культури населення його поховальна традиція, зацікавлення якою останнім часом значно зросло й відтак продукує нові якісні дослідження в цьому напрямі. Вже не перший рік вивченням середньовічної фунеральної культури на польсько-руському пограниччі займається д-р Міхал Дзік з Інституту археології Жешувського університету. Одна 3 робіт дослідника, написана на основі його дисертації, і стала об’єктом цього огляду.

Монографія “Зміни поховальних звичаїв у межиріччі Бугу і Верхньої Нарви (XI-XV ст.)” написана у двох томах (із технічних мотивів), що в цілому становить 576 сторінок. Том I складається із вступу, чотирьох розділів, списку використаних джерел i літератури, списку рисунків та таблиць, таблиці артефактів. Том II представлений шістьма розділами, післямовою, додатком, переліком джерел і літератури, списком скорочень, переліком рисунків, таблиць, а також резюме та списком пам'яток. Більшість розділів тематично поділені на підрозділи і їх підпункти.

У вступі коротко обумовлено територіальні (межиріччя Бугу та Верхньої Нарви Дорогичинська височина та Більська рівнина) та хронологічні межі роботи, акцентовано на абсолютно штучному виокремленні першої. Натомість хронологічні межі праці автор пояснює існуванням на дослідженій території групи кладовищ як у ранньому, так і пізньому Середньовіччі, а також можливістю спостережень діаметральних змін поховальної практики впродовж XI-XV ст. Зупиняється дослідник на окремих аспектах й понятійного апарату, серед яких приділяє увагу історико-географічній термінології та значенню терміна "Русь" володіння династії Рюриковичів, які пропонує розглядати в сенсі територіальному та релігійному, але аж ніяк не етнічному. Як джерельну базу використано матеріали, що зберігаються у фондових збірках: Державного археологічного музею та Інституту національної спадщини у Варшаві, Музеї Підляшшя та Воєводському управлінні охорони пам'яток у Білостоці, Археологічному музеї у Кракові, Державному історико-археологічному музеї у Гродно, Національному музеї Литви у Вільнюсі, Інституті історії матеріальної культури Російської академії наук (РАН) та Державному Ермітажі в Санкт-Петербурзі, Державному історичному музеї в Москві. Доповнює інформацію документація з Головного архіву давніх

() Луцик I., 2019 
актів у Варшаві, Державного архіву в Білостоці, Державному архіві у Кракові та наукових бібліотеках у Варшаві, Вільнюсі, Москві, Санкт-Петербурзі та Києві.

Перший і найменший розділ у монографії - “Історичний нарис регіону" - присвячений короткому огляду процесів заселення досліджуваної території та головно ії адміністративнополітичному підпорядкуванню в середньовічну добу. Автор відзначає присутність ранньослов'янських поселень, які продовжують розростатися в наступний період, про що свідчить збільшення їхньої густини у складі володінь династії Рюриковичів, одним із головних політико-адміністративним центрів яких було м. Дорогичин. Останнє, зрештою як і вся Дорогичинська земля, до кінця пізнього Середньовіччя залишалася в центрі політичних інтересів руських, мазовецьких і литовських князів.

Другий розділ - “Історія та стан досліджень поховальних пам'яток”. У ньому проаналізовано історію археологічних досліджень на зазначеній території та розглянуто основні концепції й інтерпретації їх генези. Вперше на цю проблематику в межиріччі Бугу та Нарви звернув увагу та здійснив опис поховальних конструкцій історик Вільнюського університету Юзеф Ярошевич ще в 1844 р., хоча, як зазначає Міхал Дзік, помилково інтерпретував виявлені кургани та пласкі поховання в кам'яній обкладці як ятвязькі. Відзначає автор монографії, що друга половина XIX ст. вирізнялася зацікавленням до археологічних старожитностей археологів-аматорів, які власноруч проводили розкопки, результати яких часто залишалися неопублікованими. Значну частину пам'яток на терені Більського та Сіматицького повітів розкопав податковий інспектор Сергій Сонгін. Його колекція артефактів потрапила до Вільнюса й була опублікована в музейному каталозі 1885 p. На новий якісний рівень проблематику досліджень вивів педагог, нумізмат та археолог Микола Авенаріус. Особливу увагу дослідник приділив похованням із кам'яними конструкціями, назвавши їх “кам'яними могилами”. Значний внесок у вивчення некрополів межиріччя Бугу та Верхньої Нарви зробив Федір Покровський, який уклав “Археологічну карту Гродненської губернії. Продовжили дослідження вже у XX ст. Сергій Дубінський і Роман Якимович. Естафету в них перейняли та грунтовно вивчали проблему такі відомі науковці, як: Христина Мусянович, Лехослав Раугут, Гелена Цоль-Адамікова та Марія Міськевич. На підставі результатів тривалих досліджень поховальних пам'яток виникла низка теорій їх генези. Деякі 3 дослідників відстоювали ятвязький чи мазовецьких чинник у побутуванні кам'яних поховальних конструкцій, інші на основі аналізу поховального інвентарю вбачали головно східнослов’янські чи західнослов'янські риси. Дехто зауважив на пограничному розташуванні досліджуваного терену та відзначав спільні культурні риси останніх.

Третій розділ - “Каталог пам'яток” - представлений 131 некрополем. До переліку, як зауважує автор, не ввійшло близько 140 кладовищ, для яких недостатньо хронологічних індикаторів, щоб зарахувати їх до досліджуваного періоду (XI-XV ст.). У каталозі пам'ятки подано в алфавітному порядку, а їх номер відповідає нумерації на мапах. Назву пам'ятки супроводжує інформація про адміністративне розташування, область AZP, локальна назва (топоніми тощо), якщо така існує. Кожна описана відповідно до таких критеріїв: характеристика - тип поховальної конструкції, інформація про наявність остеологічного матеріалу й інвентарю, розташування тощо; хронологія - датування на основі досліджень попередників і власних узагальнень; дослідження - інформація про вид, час пошуків та їх автора; колекції - місце зберігання матеріалів розкопок; література; примітки - уточнення і верифікація інформації. Каталог доповнений картами, планами та фото.

Розділ четвертий - "Рухомий матеріал" - складається із 29 підрозділів, які відповідають кожній із категорій поховального інвентарю: скроневі кільця, заушниці, намистини зі скла, намистини металеві, намистини з іншої сировини, підвіски, шийні гривни, браслети, персні, гудзики, пряжки та застібки, кільця, інші оздоби й елементи строю, вістря метальної зброї, наконечники стріл, меч, сокири, остроги, брязкальця, цвяхи, кресала та кремені для них, ножі та їхні піхви, точильні камені, пряслиця, серпи, шпильки, посуд глиняний, посуд з органічних матеріалів, інші знахідки. 
Варто відзначити, що автор ретельно опрацював кожну зі зазначених категорій пам'яток, детально описав функціональне призначення, сировину, форму, метричні параметри тощо, що дозволило виокремити їхні типи й підтипи. Особливу увагу зосереджено на локалізації знахідок у похованні, відповідності категоріям артефакту щодо статево-вікових ознак, соціальному статусі покійного. Всі ці результати проілюстровано низкою таблиць, графіками та діаграмами. Попри такий скрупульозний аналіз, дослідник критично наголошує на необхідності більшої вибірки матеріалів для переконливих статистичних висновків.

Чи не найчисельніші серед поховального інвентарю - жіночі головні прикраси (скроневі кільця та заушниці), порівняльний аналіз яких дозволив авторові простежити хронологічнотипологічну залежність: більший діаметр кільця оздоби - пізніший період. Серед опрацьованого матеріалу, як зауважує дослідник, вирізняються як східно-, так і західнослов'янські елементи. Особливу увагу при цьому науковець приділяє досі дискусійному питанню походження S-подібних скроневих кілець.

Перший розділ Тому II монографії - "Хронологія знахідок у світлі їх взаємного розташування у закритих комплексах". Аналіз синхронного розташування різних категорій, типів та підтипів поховального інвентарю актуальне, насамперед, для уточнення хронології предметів, а також змін поховального звичаю, еволюції строю, оздоб тощо. Детальному статистичному порівнянню й присвячений цей розділ. Так, наприклад, вдалося простежити закономірність: одночасну присутність у могилі скроневих кілець підтипу III.1 та III.2 або ж III.2 і III.3, натомість у жодному з випадків не вдалося зафіксувати одночасного розташування підтипу III.1 та III.3. На основі порівняльного аналізу вибраних категорій поховального інвентарю автор запропонував власну періодизацію, виокремивши при цьому періоди їхнього розташування в могилах: А - до другої третини або третьої чверті XI ст., B:-B.1. - від другої третини або третьої чверті XI ст. до першої чверті XII ст.; В.2. - від другої чверті XII ст. до четвертої чверті XII ст.; В.3.:-B.3.a - від кінця XII до середини XIII ст.; B.3.b. - від середини XIII до четвертої чверті XIII ст. ; C:-C.1. - кінець XIII-XIV ст.; C.2. - XV - першої чверть XVI ст. При цьому потрібно зауважити, що період А та С вирізняється відсутністю скроневих кілець [s. 24-26].

Розділ другий - “Конструкції могил”. Згідно з конструктивними особливостями поховальних пам’яток у межиріччі Бугу та Верхньої Нарви М. Дзік виділяє кургани і пласкі могили. Кургани представлені дерев'яними та кам'яними конструкціями. Останні поділяє на типи: I - з кількашаровим мощенням каменю від підніжжя насипу; II - 3 кам'яним плащем, що прикривав насип; III - без мощення, але з кільцем із поодиноких каменів довкола основи; IV 3 численними каменями, що виступають на різних рівнях насипу, але не становлять виразної конструкції [s. 36-39]. Натомість пласкі могили дослідник поділив на: I - без ями, з кам'яним мощенням та обкладкою; II - з ямою (глибиною до та понад 0,3 м) із кам'яним мощенням та обкладкою; III - з ямою без кам'яних конструкцій чи з такою конструкцією, в якій одночасно не було бруку й обкладки [s. 40-48]. Побутування курганів притаманне періодам А, В.1, В.2, пласкі ж поховання - всьому періоду В, а типи II та III пласких поховань - С.

Розділ третій - “Поховання". Рештки покійників, похованих за обрядом інгумації, вдалося зафіксувати в 600-х могилах. Стан збереження більшості тлінків вкрай поганий, що суттєво ускладнило ї опрацювання. Проаналізовані матеріали хронологічно поділені на періоди В та С. Орієнтація покійників переважно західна, хоча трапляється і східна. Кількість ж решток, придатних для визначення аспектів розташування тіла у гробi, не перевищує 200. Простежено переважання укладу рук на тілі (на грудях, животі, тазі в різних комбінаціях) у періоді С порівняно з періодом В. Окремо зосереджено увагу на кількості й локалізації померлих у курганах та пласких могилах, підпохованнях у пізніші періоди.

Практика кремації на досліджуваній території притаманна для курганних поховань у період А, можливо А-B, та пласких поховань в основному у період В. М. Дзік, аналізуючи рештки кремації, наголошує на питанні часткового спалення небіжчиків та місцях, де воно відбувалося. 
Четвертий розділ - “Кладовища в середньовічному ландшафті”. У ньому розглянуто топографію середньовічних некрополів у контексті природного середовища та розташування відносно населених пунктів, а також власної внутрішньої структури (орієнтації, моделі закладання поховальної конструкції: моноцентричної чи поліцентричної). Дослідник відзначив розташування кладовища переважно на західній експозиції схилу, близьке до водотоків і поселень (0,2-0,6 км), північно-східному від останніх тощо. Винятки - поховальні пам'ятки в Дорогичині з огляду на їх ймовірно прицерковне розташування.

П’ятий розділ - “Деякі сліди звичаїв, що супроводжують поховання”. Розглянуто значення вогню та слідів його дії безпосередньо в похованні чи могильних конструкціях інгумаційних могильників. Запропоновано низку інтерпретацій, які пояснюють наявність залишків попелу й вугілля в похованні, серед яких як утилітарні, так і апотропеїчні тощо. У подібному контексті автор розглядає кам'яні конструкції та дерев’яні домовини в похованнях. При цьому аналізує їх форму, параметри, способи виготовлення та сировину. Коротко зупиняється на віднайдених тваринних і рослинних рештках.

В останньому, шостому, розділ - “Заселення регіону в світлі матеріалів з кладовищ” М. Дзік розглядає впливи християнських та міграційних чинників на формування і зміни поховальних звичаїв у межиріччі Бугу та Верхньої Нарви. Аналіз наявних писемних й археологічних джерел залишає відкритим питання шляху поширення християнства в досліджуваному регіоні. Із християнською обрядовістю цього періоду пов'язані інгумаційні поховання, поява яких припадає на XI ст. Однозначної відповіді немає й щодо конкретного етнічного впливу на формування наявної поховальної традиції в період А. Розгляд поховальних пам'яток у контексті заселення регіону в цей час має, на думку дослідника, радше загальнослов'янські, а не виразно етнічні риси.

У період В1-B2 обряд кремації замінив обряд інгумації. Поширення набувають поховання у пласких могилах із кам'яними конструкціями. Автор монографії відзначив відмінності поховальних звичаїв і виокремив три зони: 1 - середня частина Дорогичинської височини; 2 - Дорогичин та найближчі околиці; 3 - басейн р. Нарви. Але ці зміни вбачає швидше в поступовій еволюції локальних форм могил, а не у наслідку міграції в XI-XII ст. населення зі заходу чи сходу. Хоча очевидний факт, що на момент появи держав П’ястів i Рюриковичів ці терени пограничні і входять у сферу зацікавлень обох. Щодо поховального інвентарю, то категорії знахідок не виступають у рівних пропорціях - переважають то предмети західного, то східного походження. Дискусійним при цьому залишається питання походження S-подібних скроневих кілець. Останні дослідник вважає свідченням зв'язків і присутності західнослов'янської культурної спільноти на терені. Домінування цих західних впливів, на думку автора, закінчилося в період В1.

Період В3 характеризується закінченням побутування курганів, меншою кількістю інвентарю, появою поховань типу III, при цьому кладовища все ще розташовували за межами поселення. Незважаючи на належність цього регіону до Русі, автор відзначає все ще стійкий мазовецький влив на заході.

Період C - XIII-XV ст. представлений головно похованнями типу III, які в XIV ст. становили єдину форму могил, на деяких із них з'являються кам'яні стели з вирізьбленим хрестом. Більшість поховань безінвентарні, що ускладнює ідентифікацію їх хронології чи етнічної належності. Особливість цього часу - звичай підпоховання небіжчиків у старі кургани. 3 кінця XIV ст. межиріччя Бугу та Верхньої Нарви вирізнялося інтенсивними процесами колонізації мазовшанами та литовцями, а відтак існуванням як католицької, так і православної парафій, а отже, й поховальних традицій.

Підсумовуючи, М. Дзік зазначає, що досліджений матеріал не дозволяє зробити однозначні висновки щодо етнічної належності місцевого населення, а відтак залучити його чи то до східно-, чи то до західнослов'янської групи. Натомість порушена проблематика потребує подальшого вивчення, збільшення джерельної бази та залучення широкого кола спеціалістів. 
Огляд цього монографічного дослідження дає змогу констатувати, що автор опрацював велику джерельну базу, вперше комплексно зібрав напрацювання попередників, здійснив їх верифікацію. Це дозволило скласти детальний каталог пам'яток, на основі якого здійснив порівняльний аналіз поховальних конструкцій, інвентарю, відтак виокремив типологію та хронологію пам'яток, а отже, простежив зміни поховального обряду на досліджуваній території впродовж XI-XV ст. Це дослідження, без сумніву, - вагомий внесок у розвиток проблематики середньовічної фунеральної культури не тільки польсько-руського пограниччя, а й генези та еволюції поховального обряду Центральної і Східної Європи. 